\title{
INNOVATIONS IN THE DIMENSION OF COMMUNICATION IN HEALTH SECTOR AND THE PERSPECTIVE OF SOCIETY 5.0
}

\author{
Szymon JOPKIEWICZ ${ }^{*}$, Agata JOPKIEWICZ ${ }^{2}$ \\ ${ }^{1}$ Jan Kochanowski University, Faculty of Law and Social Science, Department of Management; \\ szymon.jopkiewicz@ujk.edu.pl, ORCID: 0000-0001-5289-6820 \\ ${ }^{2}$ Jan Kochanowski University, Faculty of Pedagogy and Psychology, Institute of Adult Education; \\ agata.jopkiewicz@ujk.edu.pl, ORCID: 0000-0003-2198-2069 \\ * Correspondence author
}

Purpose: The aim of the article is to present the perceptions of ICT in times of the development of Society 5.0 in the awareness of beneficiaries of the healthcare system, and outlining the prospects of applying these solutions in the health sector.

Design/methodology/approach: The research was conducted in Świętokrzyskie Voivodeship. The questionnaire was used to survey people using primary healthcare services.

Findings: The respondents identified the importance of various forms of using ICT by primary healthcare entities, specifying their preferred information communication channel. The greatest number of indications, nearly $92 \%$ of the respondents, chose a direct contact with the doctor as important or very important.

Originality/value: The health sector in Poland, as well as in other countries of the EU, has been the subject of constant changes though they are not clearly visible for the general public. Technological progress and the related innovations in the field of communication are an opportunity to improve the information flow between the doctor and patient. Moreover, they facilitate gaining knowledge and thus constitute an important dimension in the process of learning in the perspective of Society 5.0 development. New ICT channels may be an important method for the health sector to find ways of reducing the costs of patient service.

Keywords: health sector, ICT, Society 5.0.

\section{Introduction}

The impact of modern technology on the healthcare system has become increasingly important in recent years. The health sector in Poland, as well as in other countries of the EU, has been the subject of constant changes though they are not clearly visible for the general public. Technological progress and the related innovations in the field of communication are an opportunity to improve the information flow between the doctor and patient. Moreover, 
they facilitate gaining knowledge and thus constitute an important dimension in the process of learning in the perspective of Society 5.0 development.

Functioning of healthcare sector in Poland and in other EU countries is the result of many political and economic conditions taking place over time. The economic conditions are important as the changes in healthcare create a wide variety of organizational and financial forms (Świder, 2004) connected by a common information network.

Society 5.0 is the idea of a modern, future-oriented and human-centred society, in which the unity of the real and virtual world is realised through technologies, e.g. Artificial Intelligence, Internet of Things, robotics or Big Data. According to this concept, the aim of the society will be to create a reality in which services will be provided to everyone at any time and place, regardless of the region, age, gender, language, i.e. without limitations, with the simultaneous economic growth and prosperity and overcoming social challenges, thus contributing to the prosperity of global society (du Val, 2019). Society 5.0 is more precisely described in the Japanese approach, which promotes a model of inter-human relations focused on an individual (human-centric society), where the economic progress serves to solve social problems through the system and technologies which integrate virtual and physical space. It is, therefore, the society which is characterised by a higher level of integration, in which interrelated realities - the digital one and the real one - facilitate embedding virtual space in the real world. Such society can be called super-intelligent or creative. It is the subsequent, fifth stage in the evolution of societies, following the hunting society, agricultural society, industrial society or information society that we have nowadays (Tworóg, Mieczkowski, 2019).

Building and maintaining an effective healthcare system is not easy and can be influenced by the following aspects: ageing society, constant mobility of people, low effectiveness of financial resources from public funds spent on health services. What is more, the problem of cost intensity of the new medical technologies is growing. These issues lead to the conclusion that new ways of implementing innovative solutions must be searched for, which will provide for effective distribution of financial means and improve information flow, and thus the control over the functioning of the whole healthcare system in Society 5.0.

Therefore, the use of ICT is of key importance to improve the quality of services offered in health sector. The widespread introduction of information-communication technologies will provide cost-effective care, among others, based on models of data management such as Big Data or Data Mining. Although in some cases the approach is used frequently, in the global scale digital tools are still rare, which results from the fact that implementing ICT in healthcare is a process, not a single action. The long term nature of changes allows both the medical personnel and patients to adapt to developing needs and new challenges (Batko, 2017). The difficulties which can be encountered while implementing innovative solutions include, primarily, the limited access to technologies, problems of integrating them with the work of medical personnel and concerns related to privacy and data security. The obstacles are being overcome, but not quickly enough. Therefore, new information-communication technologies 
creating intelligent solutions for sectors of economy and functioning organisations can be an alternative in addressing the needs of the developing Society 5.0. ICT can provide high quality of services, giving an opportunity to build a cost-effective system of healthcare.

Acknowledging that scientific discoveries and innovations are intermediary forces connecting different sectors, countries and regions, their cooperation should contribute to achieving the goals of sustainable development. Parallel assumptions constitute the basis of the European idea of Responsible Research \& Innovation (RRI), which emphasises that research and innovation should take into consideration complex reality and respond to its demands. The challenges facing the Old Continent were outlined in the Europe 2020 strategy, and include, among others, such areas as health, demographic changes and prosperity; food, agriculture, forestry and water; safe, clean and efficient energy; smart, ecological, integrated transport; climate, environment and natural resources (du Val, 2019). Realising the idea of Society 5.0, the above mentioned activities should concern all countries, all the regions in them, regardless of their GDP, so as to equalize living standards and access to highly-qualified services.

Therefore, the aim of the article is to present the perceptions of ICT in times of the development of Society 5.0 in the awareness of potential beneficiaries of the healthcare system, and outlining the prospects of applying these solutions in the health sector.

\section{Technological Innovations and Health - the Role of Information Flow in the Perspective of Society 5.0.}

Global trends and recommendations of WHO and national health organisations leave no doubt that digitalisation of healthcare is the only right procedure, especially in the context of Society 5.0. According to WHO, e-health is the only way to overcome the limitations of a traditional healthcare system which constitute the so-called health system challenges (HSC). The World Health Organisation points to three main challenges of healthcare (Chojnacki, Chromiec, 2019):

1. Insufficient resources, both human and material, which can be overcome by creating programs for optimising certain activities to be performed without human intervention (e.g. administrative matters).

2. Lack of data or access to data, which can be counteracted by using automatic recording of diagnostic tests results, creating an electronic platform of medical documentation, as well as creating medical data registers.

3. Deficiencies in monitoring patients' condition, follow-ups which could be realised e.g. by using applications connected to medical devices to monitor automatically patients' health or patient empowerment. 
Information-communication technologies are a driving force of economic, scientific and technological development (Watanabe et al., 2015), and an important source of competitive advantages (Iniesta-Bonillo et al., 2013). Their functioning in terms of support for specific sectors of economy is varied and changes over time.

Currently ICT is one of the most dynamically developing sectors of economy, its implementation on the level of enterprises and skilful use of related technologies are one of the most important stimuli influencing the increase of productivity (Venturini, 2015) and vitalising the economy. The diffusion of information and knowledge connected with applying ICT in sectors of economy is accelerated when the networks of cooperating units are geographically concentrated, therefore the need to use ICT systems and increase cooperation between them (Juchniewicz, Grzybowska, 2010). The above mentioned situation takes place in the health sector, where the ongoing process of marketisation, and the related dynamic development of technologies have improved task coordination and control over the distribution of public funds. Moreover, the effective use of technologies in healthcare sector allows for receiving up-to-date information about the beneficiaries of the system, which can affect the quality of services offered and reduce the costs of patient service.

The development of ICT has been gradually changing practically every aspect of social life (Rattle 2010), starting from business transactions, everyday routine, lifestyle and ending with politics or economics. Consequently, new aspects emerge and deserve attention: e-economy, e-democracy, e-education, e-trade, e-business, e-banking, e-taxes and e-health (Çilan, 2009).

Changes that are brought by the ICT revolution and globalisation trigger a discussion in areas related to health and information flow which facilitate learning process in organisations and societies:

- demographic changes in developed and developing countries. Currently, there are approximately 7 billion people in the world (Social, Digital and Mobile Worldwide, 2012). The UN estimates indicate that by the year 2053 there will be over 9 billion people on Earth. This will happen due to increasing improvement of the quality of healthcare, and more precisely technological development in that area, more effective disease control and global economic development (Friedman, 2008).

- increased financial burdening of the state budget with the cost of healthcare (Gartner, 2009), which is the challenge even for the richest countries in the world (Roper et al., 2011).

ICT may be an element of improvement and reducing the expenses on healthcare systems, however much will depend on the level of its implementation and costs which can be paid by the stakeholders of the service relation. There are three levels of ICT services for communication and knowledge exchange: 
1. Links and networks: email, telecommunication infrastructure, cables, satellites.

2. Public information and communication: government information, crucial information for the community, public broadband network.

3. Information and communication connected with healthcare (von Dijk, 2006).

Referring to healthcare, it is indicated that an important argument for the use of modern technologies in this segment is obtaining accurate information about a patient, sharing knowledge, educating patients, and thus the process of learning an organisation in interaction with the environment. Moreover, ICT usage allows for reducing the costs of medical services. This matter is of crucial importance especially in relation to Polish healthcare system (Andreassen, 2012), where one can observe a constant increase of costs of a single patient's service, connected with low reimbursement from the National Health Fund (Narodowy Fundusz Zdrowia NFZ) in relation to the growing number of long-living pensioners - the main beneficiaries of the system. Therefore, it is reasonable to search for reduction in at least part of the costs generated by the healthcare system. Obtaining complete and fast information about a patient, knowledge exchange - interactive process of learning through the use of information technologies.

The above mentioned areas open a perspective of improving the flow of information, triggering the process of learning, the beneficiary of which becomes a health sector unit, obtaining up-to-date knowledge and the possibility of reaction, which facilitates the process of treatment, and additionally engages the patient to consciously build knowledge about his/her health condition.

\section{E-Health in the Dimension of Information-Communication Technologies in the Health Sector}

The term e-health can be interpreted as the use of ICT in all activities that relate to the healthcare sector (Dąbrowska, 2009) and refers to health information portals, electronic records, telemedicine services, personal portable communication devices (Andreassen, 2012) and many other ICT tools used in preventive actions, diagnosing, treatment or monitoring health condition (Dąbrowska, 2009). Generally speaking, e-health is applying ICT in the healthcare sector (Pawar et al., 2012). New information communication technologies are important not only in terms of improving the quality of patient service, but also bring certain economic benefits. They mean better compliance with the doctor's recommendations: the number of ordered diagnostic and specialistic tests, frequency of visits or the length of hospitalisation and the overall duration of treatment (Charles et al., 2000). In times of problems with the public health service functioning and lack of access to certain services, the fact of reducing costs of patient care thanks to effective communication through ICT seems invaluable. 
E-health covers several healthcare and information technology services, e.g. (Dąbrowska, 2009):

- electronic medical records which facilitate the exchange of patient data between healthcare entities (general practitioners, specialists, hospital teams and pharmacists);

- telemedicine covering all sorts of tests and measurements which do not require a patient's visit to a specialist;

- medicine based on scientific evidence which includes a system providing information on the proper treatment for a certain patient's condition;

- consumer healthcare information technology which allows for the access to information on certain issues from the area of medicine;

- healthcare knowledge management - specialistic access to medical information;

- virtual healthcare teams which include healthcare professionals who pass on information about patients through digital devices.

\section{Materials and Methods}

The research was conducted in Świętokrzyskie Voivodeship, which belongs to the so-called eastern wall i.e. the region with the lowest share in GDP $(2.3 \%$ according to the Central Statistical Office data of 2018). The questionnaire was used to survey people using primary healthcare services (POZ). The group under study was diversified in terms of the place of residence (small towns and cities with more than 100,000 inhabitants), with nearly half of the respondents being the residents of urban areas and the rest from rural areas, age (50-59 years old), as well as gender - women constituted $70.14 \%$ and men nearly $30.00 \%$ of the respondents, and education - people with higher education accounted for $13 \%$, while $64 \%$ had secondary education. People with primary or vocational education constituted a little over $22 \%$. The most numerous group were women with secondary education $-67 \%$ of the respondents, whereas men with the same education accounted for $57 \%$ of the respondents.

\section{Results}

The respondents identified the importance of various forms of using ICT by primary healthcare entities (POZ), specifying their preferred information communication channel the telephone, the Internet, direct contact with medical personnel. The greatest number of indications, nearly $92 \%$ of the respondents, chose a direct contact with the doctor as important or very important. The category of tele-advice with the use of a telephone was chosen by just 
over $66 \%$ of the respondents. Whereas online contact was indicated as important by $27 \%$ of the people under study, which may come as a surprise in times of digitalisation of the health sector, the more so that the category of online contacts with a health sector unit was picked up by nearly $40 \%$. In turn, the category of contact with other patients through ICT tools was crucial for every fourth of the respondents, which may prove that a number of patients need additional information and/or a "group support". C to C communication is the arena for exchanging patients' knowledge and experiences important from the perspective of their dilemmas.

Table 1.

Forms of communication in service relations of the health sector entities (\%)

\begin{tabular}{|l|c|c|c|c|c|}
\hline \multicolumn{1}{|c|}{ Opinion } & $\begin{array}{c}\text { Totally } \\
\text { unimportant }\end{array}$ & $\begin{array}{c}\text { Rather } \\
\text { unimportant }\end{array}$ & $\begin{array}{c}\text { Neither } \\
\text { important nor } \\
\text { unimportant }\end{array}$ & $\begin{array}{c}\text { Quite } \\
\text { important }\end{array}$ & $\begin{array}{c}\text { Very } \\
\text { important }\end{array}$ \\
\hline direct contact with the doctor & 0,72 & 3,23 & 3,94 & 38,35 & 53,76 \\
\hline $\begin{array}{l}\text { tele-advice from the doctor with } \\
\text { the use of a telephone }\end{array}$ & 3,23 & 12,19 & 18,28 & 46,24 & 20,07 \\
\hline online contact with the doctor & 16,85 & 25,45 & 30,47 & 22,22 & 5,02 \\
\hline $\begin{array}{l}\text { online contact with the medical } \\
\text { entity }\end{array}$ & 11,11 & 18,64 & 31,54 & 30,47 & 8,24 \\
\hline $\begin{array}{l}\text { contact with other patients with } \\
\text { the use of ICT (C to C) }\end{array}$ & 21,15 & 26,88 & 27,96 & 18,28 & 5,73 \\
\hline
\end{tabular}

Source: Authors' study.

\section{Summary}

The idea of Society 5.0 which assumes the development of economy in cooperation between physical and digital environment realised though technologies may encounter certain barriers resulting from region-specific features, customs, habits and mentality, as well as the level of education in local communities in terms of access to and operating ICT devices. Therefore, despite the EU directives, governments, international organisations e.g. WHO, on the local level still the prevailing role in the preferred by patients forms of interaction may be given to the direct contact with the doctor, being the core of the service and the guarantee of quality and safety of the health service. Slightly different results in this matter were obtained in research carried out by the Future Health Index (FHI) in 2019 which indicate that $36 \%$ of patients are willing to undergo remote medial consultations in situations where the direct contact with the doctor is not necessary (2019 FHI Report), and 85\% of patients prefer to make appointments online, which differs from the indications obtained from the survey by $30-50 \%$. Such discrepancy can be explained, inter alia, by the lack of certainty or patients' trust as to the safety of collected data, and/or low awareness concerning the advantages of implementing ICT tools in the health sector. 
A significant role in increasing patients' awareness and encouraging them to use digital tools may by played by medical personnel who by recommendations can educate and provide knowledge on the use of ICT. In other words, the communication process leads to learning in service interactions, as a result of which the new value is created in the form of up-to-date knowledge. Thus, it will be necessary to share information about data security and benefits resulting from digital solutions for patients offered by health institutions.

It is worth noticing the role of digital interactive ITC media which, though unable to eliminate the direct contact, as it is indispensable, may create its valuable supplement. It may refer to activities like registration, additional information or consultation via a telephone or ICT. Introducing new interpersonal means of communication for patients may be a significant convenience, and for the health sector an important method of searching for ways of reducing the costs of patient service. Moreover, the development of digital media creates a chance to expand the activities connected with disease prevention. It is also another opportunity to reduce the high costs of health service in Poland.

\section{Conclusion}

1. The surveyed group identifies effective forms of communication with service providers with new ICT technologies, the role of institutions and their personnel will be to improve the ways of communication preferred by patients, which may favour the development of the idea of Society 5.0 in the health services sector.

2. Although the dominant method in the communication between a patient, doctor and personnel is still the direct contact, the respondents (aged 50-59) begin to notice the significant role of digital ICT media.

3. New ICT channels may be an important method for the health sector to find ways of reducing the costs of patient service. Moreover, their advancement creates an opportunity for learning processes which are essential in times of Society 5.0 development. 


\section{References}

1. Andreassen, H. (2012). ICT and patient roles; contradictions in e-health policy. Health Policy and Technology, Vol. 1, Iss. 2, pp. 88-89.

2. Batko, K. (2017). Możliwości wykorzystania systemów analitycznych w usprawnianiu opieki zdrowotnej. Zeszyty Naukowe Uniwersytetu Ekonomicznego w Katowicach. Uniwersytet Ekonomiczny w Katowicach. nr 316, p. 45.

3. Charles, C., Gafin, A., Whelan, T. (2000). How to improve communication between doctor and patients. British Medical Journal, Vol. 320, pp. 1220-1221.

4. Chojnacki, M., Chromiec, Z. at al. (2019). Pokłady cyfrowego bogactwa w stużbie pacjentom, czyli o wykorzystaniu potencjału danych $w$ sektorze ochrony zdrowia. Raport Alumnów Projektu „Liderzy Ochrony Zdrowia” Fundacji im. Lesława A. Pagi, p. 83.

5. Çilan, Ç.A., Bolat, B.A., Coşkun, E. (2009). Analyzing digital divide within and between member and candidate countries of European Union. Government Information Quarterly, Vol. 26, Iss. 1, p. 98.

6. Dąbrowska, A. (2009). Charakterystyka wybranych e-usług na polskim rynku. In: A. Dąbrowska, M. Jakoś-Kresło, A. Wódkowski (eds.), E-usługi a społeczeństwo informacyjne (pp. 96-98). Warszawa: Difin.

7. du Vall, M. (2019). Super inteligentne społeczeństwo skoncentrowane na ludziach, czyli o idei Społeczeństwa 5.0 słów kilka. Państwo i Społeczeństwo, nr 2, pp. 11-31.

8. eHealth for a Healthier Europe! - opportunities for a better use of healthcare resources (2009). Gartner, p. 7.

9. Friedman, T.L. (2008). Hot, Flat and Crowded. Why We Need a Green Revolution And How It Can Renew America. New York: Farrar, Stratus and Giroux, pp. 27-28.

10. Iniesta-Bonillo, M.A., Sanchez-Fernandez, R., Schlesinger, W. (2013). Investigating factors that influence on ICT usage in higher education: a descriptive analysis. International Review on Public and Nonprofit Marketing, Vol. 10, Iss. 2, pp. 163-164.

11. Juchniewicz, M., Grzybowska, B. (2010). Innowacyjność mikroprzedsiębiorstw w Polsce. Warszawa: PARP, pp. 36-37.

12. Pawar, P., Jones, V., van Beijnum, F., Hermenes, H. (2012). A framework for the comparison of mobile patient monitoring systems. Journal of Biomedical Informatics, Vol. 45, Iss. 3, p. 544.

13. Rattle, R. (2010). Computing Our Way to Paradise? The Role of Internet and Communication Technologies in Sustainable Consumption and Globalization. LanhamNew York-Toronto-Plymouth: Altamira Press, p. 1.

14. Roper, A.T., Cunningham, S.W., Porter, A.L., Mason, T.W., Rossini, F.A., Banks, J. (2011). Forecasting and Management of Technology. Hoboken: John Wiley \& Sons, p. 11. 
15. Social, Digital and Mobile Worldwide. The Key Numbers for Each Region Around the Globe. We Are Social, January 2012, p. 2.

16. Świder, P. (2004). Skuteczność a system finansowania ochrony zdrowia w krajach Unii Europejskiej - porównania. Problemy Zarządzania, Ochrona zdrowia, No. 4(6), p. 7.

17. Tworóg, J., Mieczkowski, P. (2019). Krótka opowieść o gospodarce 5.0, czyli jak żyć i funkcjonować w dobie gospodarki 4.0 i sieci $5 G$. Warszawa: Krajowa Izba Gospodarcza Elektroniki i Telekomunikacji, Fundacja DigitalPoland, p. 28.

18. Venturini, F. (2015). The modern drivers of productivity. Research Policy, Vol. 44, Iss. 2, pp. 359-361.

19. von Dijk, J. (2006). The Network Society. Social Aspects of New Media. London-Thousand Oaks-New Delhi: SAGE Publications, pp. 254-255.

20. Watanabe, Ch., Naveed, K., Zhao, W. (2015). New Paradigm of ICT productivity Increasing role of un-captured GDP and growing anger consumers. Technology in Society, Vol. 41, p. 29. 